\title{
ПЕПТИДНЫЙ МИМЕТИК 2-Й ПЕТЛИМОЗГОВОГО НЕЙРОТРОФИЧЕСКОГО ФАКТОРА ОСЛАБЛЯЕТ ТРЕВОЖНУЮ РЕАКЦИЮ НА СТРЕСС У МЫШЕЙ
}

\author{
Е.М. Григоревских ${ }^{1,2}$, А.В. Надорова ${ }^{1}$, С.А. Лебедева ${ }^{2}$, Л.Г. Колик ${ }^{1}$ \\ ${ }^{1}$ Лаборатория фармакологической регуляции состояний зависимости, \\ ФГБНУ «НИИ Фармакологии им. В.В. Закусова»,125315, г. Москва, ул. Балтийская, 8. \\ ${ }^{2}$ Кафедра фармакологии Института Фармации им. А.П. Нелюбина, \\ ФГАОУ ВО Первый МГМУ им. И.М. Сеченова, \\ 119435, Россия, г. Москва, ул. Большая Пироговская, д. 2, стр. 4.
}

DOI: 10.19163/MedChemRussia2021-2021-506

E-mail: catarinagrig@gmail.com

Ранее было показано,что миметик 4-й петли мозгового нейротрофического фактора (BDNF) ГСБ-106при взаимодействии с TrkB рецепторами активируетпострецепторные сигнальные пути (PI3K/AKT и MAPK/ERK1/2) и проявляет анксиолитическую активность [1]. Синтезированный в НИИ фармакологии имени В.В. Закусова миметик 2 й петли BDNF (ГTС 201)на культуре клеток активировалтолько MAPK/ERK1/2 путь. Целью исследования было изучение возможного анксиолитического действия ГТС-201 в опытах invivo.

Эксперименты выполнены на беспородных половозрелых мышах самцах CD-1 и на инбредных мышах-самцах линии BALB/Cc выраженной тревожной реакцией на эмоциональный стресс. Оценку тревожного поведения проводили в тесте «приподнятый крестообразный лабиринт» (ПКЛ, ООО «Открытая наука»), спонтанную двигательную активность регистрировали с помощью актометра(OptoVarimex, США). Увеличение времени нахождения в открытых рукавах при отсутствии изменений двигательной активности рассматривали как проявление анксиолитического эффекта. Статистическую обработку полученных результатов проводили с использованием однофакторного дисперсионного анализа (ANOVA) и t-критерия Стьюдента $(\alpha=0.05)$. При изучении противотревожного действия ГТС201 в диапазоне доз 0,1 - 5,0 мг/Кг, в/б, в тесте ПКЛ установлено, что у мышей CD-1 миметик дозозависимов дозе 1,0 мг/кг увеличивал число выходов в открытые рукава по сравнению с контрольной группой $(1,7 \pm 0,5$ vs $0,5 \pm 0,2, p \leqslant 0,05)$, не влияя на общую двигательную активность животных. У мышей BALB/сГTC-201 в дозах 0,5 и 1,0 мг/кг, в/б, статистически значимо увеличивал время пребывания в открытых рукавах лабиринта по сравнению с контрольной группой в 2,44 и 2,9 раз соответственно. При оценке спонтанной двигательной активности ГТС-201 при однократном и субхроническом введении не вызывал изменений локомоторной активности, что позволяет исключить психостимулирующее действие. Полученные данные свидетельствуют о выявлении анксиолитической активности в фармакологическом профиле низкомолекулярного миметика2-й петли BDNF.

\section{Литература}

[1] Колик Л.Г., Надорова А.В., Григоревских Е.М., Эксп. и клиническая фармакология. 2020, Том 83, №11, С. 3-7

[2] Гудашева Т.А., Тарасюк А.В.и др., Фармакокинетика и фармакодинамика. 2017, №3, С. 3-13 